\title{
IMPACT OF STEEL INDUSTRY ON FREIGHT RAILWAY MAKRET IN CENTRAL EUROPE
}

\author{
Abstract. The interconnection of Eurasia through logistics chains using rail transport as the main mode of transport \\ brings many opportunities for EU member states with Chinas economic potential. Accelerating the import of goods \\ and semi-finished products into domestic industrial production from China by railway may pose a risk to the economic \\ performance of countries that depend on industrial production and its structures. \\ Keywords: Steel Industry, Freight transport, Railway transport, GDP, Economy \\ Štefan Čarný1 \\ ${ }^{1}$ Faculty of Operational and Economics of Transport and Communications University of Žilina, \\ Univerzitná 8215/1, 01026 Žilina; +421/41 513 3434; stefan.carny@fpedas.uniza.sk
}

\section{Introduction}

The historical development of rail transport is closely linked to the transport of bulk substrates over long distances in order to ensure the highest possible efficiency of continental freight transport per unit of transport capacity. By reducing the energy consumption per unit of transport performance, we are drastically reducing the number of consumed resources.

The demand for transportation of bulk substrates in Central Europe stems from its economic nature. In most Central European countries, industrial production accounts for the largest share of total GDP.

The largest processor of bulk substrates in the conditions of the Slovak Republic and the countries of Central Europe is the metallurgical industry and energy industry, the metallurgical industry forms the core of the entire industrial production with connection to other sectors of the national economy, such as automotive industry, construction, transport, etc.

The concept of railway tracks was largely influenced by the location of ironworks and heavy industry companies to ensure their smooth supply of materials. The largest importers of these materials are eastern countries, especially Ukraine and the Russian Federation.

The cessation of production or the reduction of production volumes on ironworks in the countries of Central Europe poses a great risk. Ironworks provides an irreplaceable number of job opportunities in many regions. However, the connection of the metallurgical industry is further linked to other industries and services.

Securing the supply of material flow into the heavy industry is ensured by freight railway transport, because of its natural properties. Railway transport represents the most efficient, reliable and at the same time keyway of securing the supply of material and the transport of finished products from the ironworks.

Railway carriers attribute the risk of instability in the metallurgical sector. Replacing the production of the metallurgical industry with possible imports from third countries would mean outages in transport performance and the risk of non-utilization or insufficiently equipped rolling stock.
We have recorded a rapid increase in imports of steel products in 2013-2015, when imports of these products increased several times, mainly from China. The consequences were also recorded by the ironworks in Central Europe. The ability of the market to react quickly in a short period of time precedes the legislative procedures aimed at protecting the local market. Flooding the market with products from third world countries at dumped prices brought awareness before this type of risk for our domestic market.

The current situation after the pandemic also brought with it a slowdown in the economy. A drop in demand could lead to other economic actions such as unemployment and general recession in industrial production. This period brings with it a risk of similar nature with the possibility of importing goods from abroad and this ensuring a prolongation of the recession in the industrial regions.

\section{Characteristic of metallurgical industry in Slovak republic}

The importance of industrial production in the Slovak Republic means a share of up to $24,1 \%$ in GDP. The total volume of the industry, such as mining, production and distribution of electricity, waste and water cleaning, accounts for $28 \%$ of total GDP, which makes Slovak republic one of the most industrial countries in the EU.

The fastest-growing industry is automotive. The metallurgical industry takes the 2 nd place with its share. In 2017 was a total share of $8,8 \%$ produced by the metallurgical industry.

Currently, Slovak Republic is placed 27th in total production of steel in the world. In total the metallurgy sector is divided into two sections:

SK NACE 24 - 62 companies,

SK NACE 25 - 457 companies. 


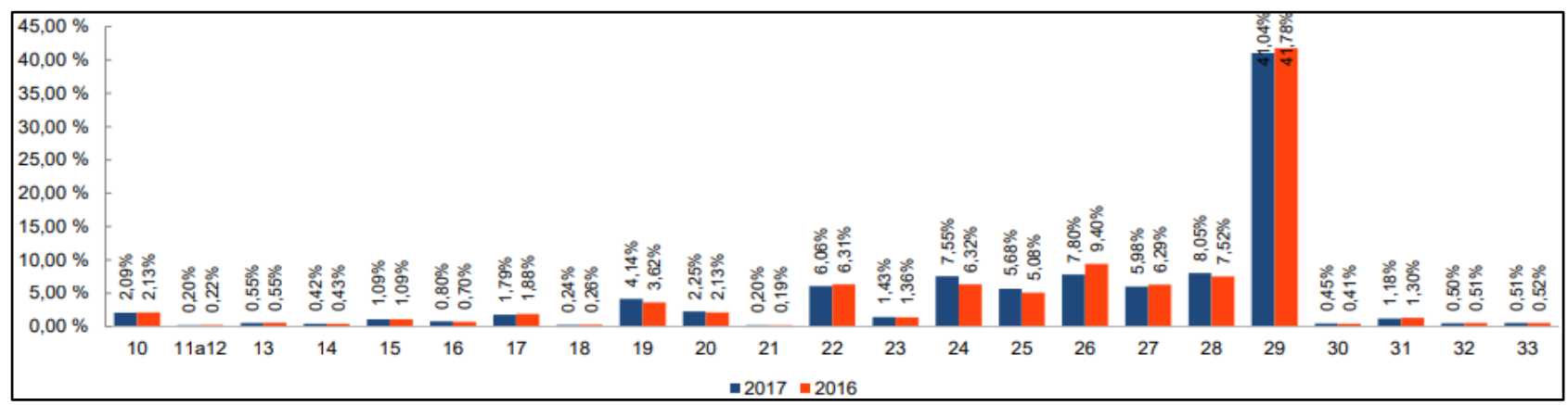

Fig. 1. The share of foreign revenues for individual sectors of the economy

Figure 1 display the share of sales from abroad in 2017 and 2016. The most important sector in the Slovak Republic is the automotive industry. The share of the metallurgical industry as the sum of SK NACE 24 and 25 is in the second place, in 2017 the share of metallurgical industry in international trade reached up to $13,23 \%$ compared to 2016 , it increases of $2 \%$, making it the fastestgrowing industry.

The downturn in the ironworks in Central Europe is strongly influenced by EU environmental policy. The metallurgical industry refers to unfair conditions stemming from EU directives and regulations for the emission trading system. In terms of the validity of this Directive, ironworks are not able to compete with products from third world countries that ensure massive steel exports to the EU. The reduction of import is currently secured with anti-dumping duty.

As a result of the regulation of this sector, it leads to a reduction in production. Tightening emission standards for heavy industry companies force them to overprice their products to cover the extra costs. However, the production of the automotive industry is closely related to the use of processed steel provided by the metallurgical industry that acts as the primary supplier to the production chain of the automotive industry. However, the cheaper steel from outside of the EU drove the automotive to reduce its production costs.

The results of these risks may lead to a similar conclusion as occurred on June 20. 2019 when U. S. Steel Košice decided to shut down blast furnace no. 2 and optimize production portfolio. At the same time, ironwork announced a reduction in the number of 2,500 employees over the course of three years. Reducing production is intended to ensure the continued operation of the business. Disruption of production and the economic indicators of the company leads to a reduction of investment plans of the company, and the possibility of transition to more environmental methods of metal processing.

\section{Characteristics and current state of U. S. Steel Košice}

The company was established on June 7, 2000. As of January 31, 2019, U. S. Steel Košice, s. r. o. consisted of 9 subsidiaries. U. S. Steel Košice has an irreplaceable position within the metallurgical industry in the Slovak
Republic. It is one of the largest steel producers in the Central European region. In terms of employment, it is the $5^{\text {th }}$ largest employer in the Slovak Republic.

In 2017, it reported the largest volume of the net profit. From 2019, the production of KORAD radiators was canceled, as well as the production of spirally welded pipes. The annual capacity of U. S. Steel Košice production is represented by 4,5 mil. tons of slabs of which in 2019 was produced 3,54 mil. tons of slabs which represent almost $80 \%$ utilization of production opportunities.

Investments and research activities are focused on the modernization of production lines and the expansion of laboratories for research and development of new materials, coatings, and surface treatments, mainly in the automotive, electrical engineering, energy, packing, and other. In 2019 The company focused its research activities on reducing production costs and the content of harmful substances released into the air.

\section{Impact of metallurgical industry on railway freight transport}

The impact of the metallurgical industry on railway freight transport stems from the natural characteristics of the goods transported by the railways. The adaptation of rail transport to industrial production in Central Europe is clearly visible from several perspectives. In terms of the dependence of rail transport, the risk is described for the national freight carrier ZSSK Cargo a. s., in tow points namely:

- The complicated political situation between Ukraine and the Russian Federation, which cause the transfer of performances around the territory of the Slovak Republic.

- High dependence on the metallurgical industry in the Slovak Republic and surrounding countries.

Both risks directly indicate a year on year decline in output in the structure of the mix of transported commodities, especially the transport of iron ore and coal. These commodities are directly linked to the EU regulatory measures and their environmental policy. In the case of long-term production decline and the increasing demand, the opportunity in PRC intensified, with imports of products at dumped prices increasing several times year on year in 2013-2015. Follow-up measures to reduce such traffic volumes were addressed in 2017

The character of railway tracks in central Europe is based on the development of countries in recent history. 
Characteristic marks of Central European railways in relation to industrial production:

- Directional and inclination conditions of railway tracks are built in the route of constant resistance,

- Composition of rolling stock of railway freight wagons

- Allocation of railway infrastructure to provide repair and maintenance of freight wagons - concentration of depots in industrial parts of the region.

- Construction of special equipment for handling bulk substrates - construction of equipment such as rotary or front trippers, etc.

The composition of the rolling stock poses a risk of not using open railway wagons, referred to $E$ - series wagons, which represent the largest part of the rolling stock. The share of these wagons in selected countries is shown in figure 2.

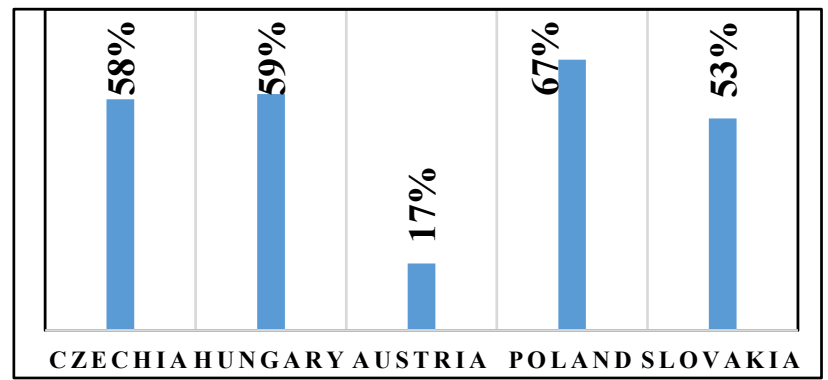

Fig. 2. Percentual amount of high sided wagons in selected countries (Source: Eurostat)

The share of high-sided wagons of a common structure makes up more than half of the total rolling stock. These wagons are directly used for the most for various types of transport, but they are mostly used for the transport of bulk substrates to the heavy industrial companies that are intended for their processing, such as iron ore and coal or wood, but they are mostly used to transportation for the metallurgical industry.

The interconnection of the metallurgical industry with other industries creates synergistic conditions for the economic growth of the country. The impact of the metallurgical industry extends to all sectors.

The import of cheaper products would mean the need to use special types of wagons for the transport of finished steel products. Currently, there is no railway freight carrier that could satisfy the need for this number of special wagons.

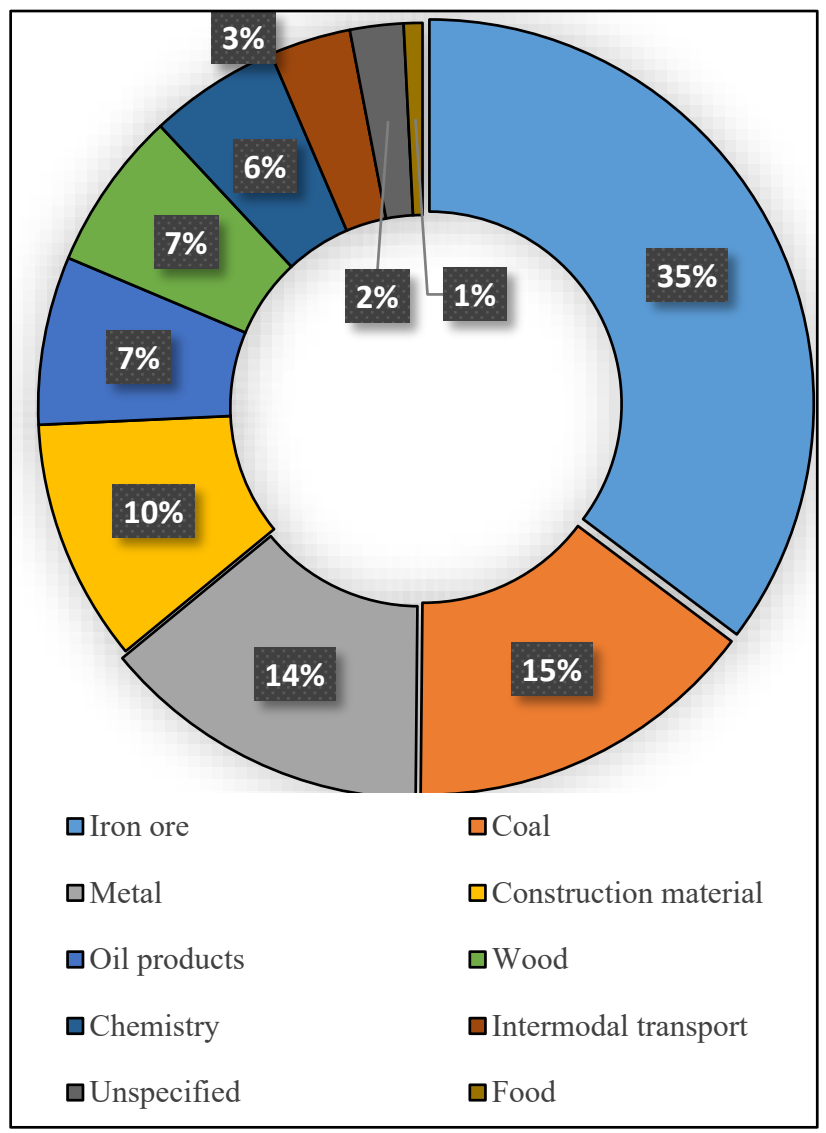

Fig. 3. Share of transported commodities in \% 2018 (Source: ZSSK Cargo)

From figure 4 we can observe a long term of decline in the transport performance of our national railway carrier. The reference period is from 2010 to 2018. The largest

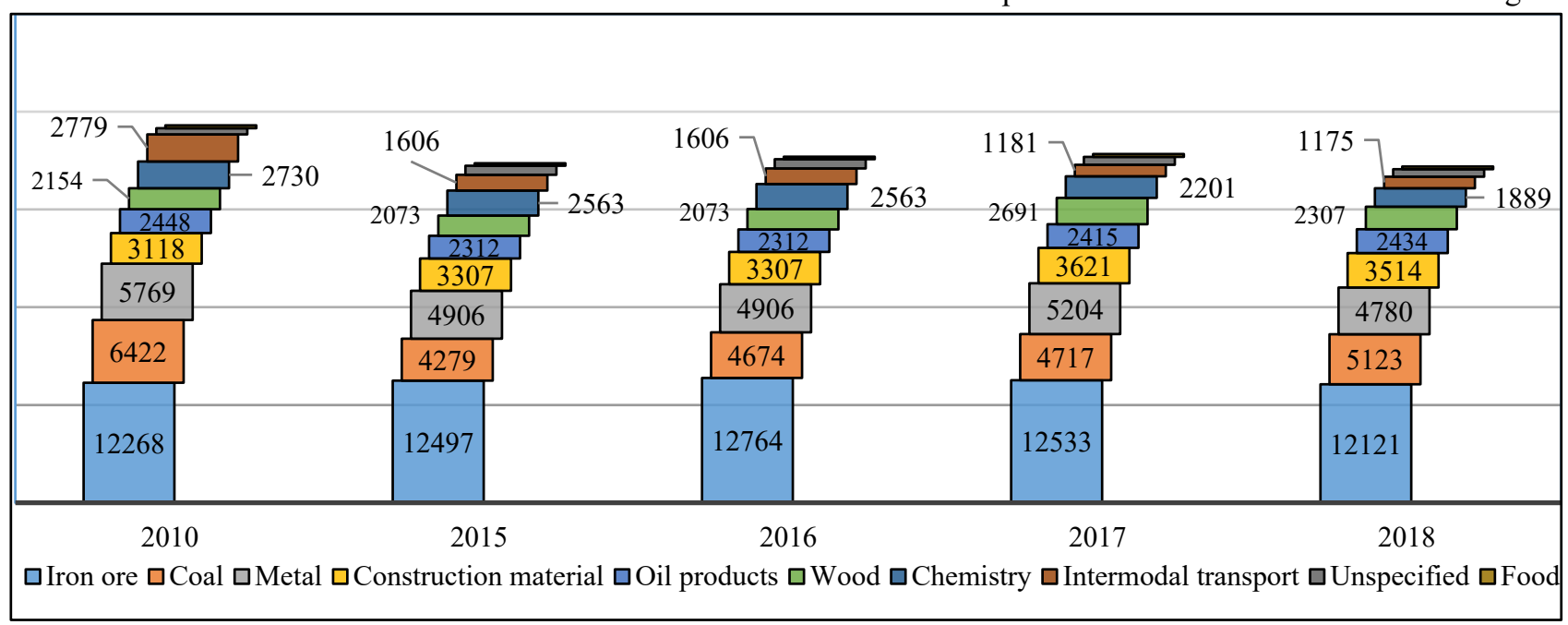

Fig. 4. Performance of freight transport (Source: ZSSK Cargo) 
shortfalls are recorded in the commodity Coal, which reduction of its usage is directly linked with the environmental policy of the EU.

The decline in other commodities stems from the gradual liberalization of the market and the arrival of competitors in the freight railway market. The largest decrease in intermodal transport, where its total volume decreased almost by half during the observed period.

Iron ore coal and the transport of metals currently represent the majority of the total volume of transport by rail. In the case of a gradual reduction in the volume of transport of these commodities, the national freight carrier is exposed to the risk of the metallurgical industry and its products can be tentatively determined in Figure no. 4, which indicates the percentage of total closure.

The sum of the volume of iron ore transport, metals, and coal are representing to be the largest share of transport of the national carrier up to $64 \%$ of the total volume in 2018. The failure of the metallurgical industry in the Slovak Republic and surrounding Central Europe would step up to every part of the industry mentioned in the previous part of the article.

\section{Conclusions}

1. Railway carriers define the risk of failure in the metallurgical industry

2. The current state of metallurgical industry in Slovak republic is in defensive strategy

3. Environmental challenges for the metallurgical industry in the EU bring the potential risk of importing cheap steel from Asia.

4. The status of the economy after pandemic could restart the imports to the local EU market

5. The potential of intercontinental transport of steel products may pose a threat to the domestic market and could cause negative economic reaction e.g. unemployment...

6. The market and its mechanics are more often overtake the process of legislation.

7. Political issues on the east between Ukraine and the Russian Federation are making

8. The decline of transport volumes of our national freight railway carrier is linked with the metallurgical industry.

9. In the case of the metallurgical industry breakdown, the rolling stock of the national carrier would be

\section{References}

Košice, U. S. S., 2019. https://www.usske.sk/. [Online] Available at: https://www.usske.sk/sk/clanok/u.-s.-steelkosice-odstavuje-vysoku-pec-c.-2-

Ministerstvo hospodárstva Slovenskej republiky, 2018. https://www.mhsr.sk/. [Online] Available at: https://www.mhsr.sk/uploads/files/ezNh8gXF.pdf

Strapáč, M., 2020. [Online] Available at: https://biznisklub.sk/wpcontent/uploads/2018/11/Anal\%C3\%BDzaHutn\%C3\%ADcky-priemysel.pdf

U. S. Steel Košice, s. r. o., 2020. Výročná správa 2018 U. S. Steel Košice, Košice: U. S. Steel Košice s. r. o..

World Steel Association, 2019. Steel statistical yearbook, Brussels: World Steel Association.

WorldSteel Association, 2020. World Steel in Figures, Brussels: World Steel Association.

ZSSK Cargo a. s., 2019. Výročná spravá 2018 ZSSK Cargo, a. s., Bratislava: ZSSK Cargo a. s..

Štatistický úrad SR Available at: https://slovak.statistics.sk)

Eurostat.euhttps://appsso.eurostat.ec.europa.eu/nui/show.do?dat aset=rail_eq_wagon_n\&lang=en 